\title{
Polityka lokalizacyjna wybranych systemów hotelowych na Kubie w zmieniających się realiach politycznych
}

\author{
Location policies of selected hotel systems \\ in Cuba under the economic crisis conditions
}

\begin{abstract}
Streszczenie: Z każdym rokiem wzrasta znaczenie Kuby na międzynarodowym rynku usług turystycznych, co uwidacznia się w wielkości zagospodarowania turystycznego oraz liczbie turystów zagranicznych odwiedzających ten kraj. Kuba stosunkowo niedawno zaistniała jako obszar znaczącej recepcji turystycznej. Długotrwała izolacja tego kraju spowodowała, że od początku lat 90. XX wieku koniecznym było podjęcie szeregu działań zmierzających do poprawy zagospodarowania turystycznego, zarówno w aspekcie ilościowym, jak i jakościowym. W opracowaniu zostanie poddana analizie polityka lokalizacyjna wybranych sieci hotelowych, zarówno zagranicznych (Sol Melia), jak i kubańskich (Cubanacan, Gaviota). Jednym z podstawowych problemów badawczych będzie przedstawienie ekspansji przestrzennej hoteli poprzez pryzmat już istniejących regionów turystycznych, ich przyrodniczej i kulturowej specyfiki, a także regionów planowanych. Dodatkowym elementem będzie analiza uwarunkowań przyrodniczych, kulturowych, infrastrukturalnych (dostępność komunikacyjna), ekonomicznych i politycznych dalszych inwestycji systemów hotelowych. Wydaje się być zasadnym stwierdzenie, że najważniejszym czynnikiem decydującym o rynku turystycznym na Kubie, szczególnie w aspekcie historycznym, był czynnik polityczny, wynikający z chęci izolacji turystów zagranicznych od miejscowej ludności, a to spowodowało powstawanie enklaw turystycznych.
\end{abstract}

\begin{abstract}
Each year the meaning of Cuba on the international tourism services market is increasing, which is visible in the size of tourism development and the amount of foreign tourists visiting the country. It was relatively recently that Cuba emerged as an area of tourist reception; prolonged isolation of the country prompted in the early 1990s the need of undertaking a variety of activities aiming at improving the state of the country's tourist infrastructure, both qualitatively and quantitatively. The case study analyzes the location policies of chosen hotel systems, both foreign (Sol Melia) and Cuban (Cubanacan, Gaviota). One of the main research issues is presenting the spatial expansion of hotels in comparison with the already existing tourism regions, their natural and cultural specification, as well as the ones yet to be developed. Additionally, the analysis of natural, cultural, infrastructural (availability of transportation), economical, and political conditions for the future investments of the hotel industry is also present. It seems valid to state that the most important factor for the development of tourism,
\end{abstract}


especially in the historical sense, was the political one, stemming from the idea of isolating foreign tourists from local inhabitants, which resulted in the emergence of tourist enclaves.

In her research, the author concentrates on the problems of tourism development in the Caribbean region. The dominating research topics are the size and spatial differentiation of tourist infrastructure and tourism volume itself together with the directions of the tourism development. The research topics also include the issue of tourist enclaves as a dominating form of tourist infrastructure in the Caribbean region in light of sustainable development and pro-poor tourism.

Słowa kluczowe: Kuba; polityka lokalizacyjna; systemy hotelowe; turystyka

Keywords: Cuba; location policies; hotel systems; tourism

\section{WSTĘP}

Kuba jest jednym z największych regionów turystyki wypoczynkowej na Karaibach. W 2012 roku kraj ten odwiedziło 2,8 mln turystów zagranicznych, pochodzących przede wszystkim z Kanady i krajów Europy Zachodniej. Do najczęściej odwiedzanych obszarów należą Hawana i Varadero, a z każdym rokiem wzrasta wielkość ruchu turystycznego w Holguin, Cayo Coco, Cayo Santa Maria i Cayo Largo Sur. Branża turystyczna generuje największą ilość wpływów dewizowych Kuby. Władze kraju są zainteresowane dalszym intensywnym rozwojem regionów turystycznych, co w konsekwencji będzie skutkowało wzrostem ruchu turystycznego i wpływów dewizowych. Jednym z podstawowych problemów badawczych będzie przedstawienie polityki lokalizacyjnej wybranych sieci hotelowych, rozpatrywanych poprzez pryzmat już istniejących regionów turystycznych. Zanalizowane też zostaną uwarunkowania przyrodnicze, kulturowe, infrastrukturalne (dostępność komunikacyjna), ekonomiczne i polityczne dalszych inwestycji systemów hotelowych. W opracowaniu zostaną przedstawione tendencje rozwojowe kubańskich ośrodków i regionów turystycznych w zakresie zagospodarowania turystycznego. Dane statystyczne pochodzą z Oficina Nacional de Estadisticas (2012).

\section{CZYNNIKI LOKALIZACJI OBIEKTÓW HOTELOWYCH}

Kuba jest jednym $\mathrm{z}$ ważniejszych regionów turystyki wypoczynkowej w regionie Karaibów, w którym znaczna część obiektów hotelowych została zlokalizowana na obszarach o wysokich walorach turystyczno-wypoczynkowych (głównie przyrodniczych), pozostających z reguły poza terenami zurbanizowanymi. Według A. Kowalczyka (2001), wśród czynników uwzględnianych przy lokalizowaniu hoteli w regionach wypoczynkowych szczególne znaczenie mają: atrakcyjność krajobrazowa, korzystny klimat, obecność wód powierzchniowych, dostępność plaż, szata roślinna. Wymienione czynniki - obok czynników infrastrukturalnych, odpowiednio wykwalifikowanej siły roboczej, powiązań kooperacyjnych czy sprzyjających przepisów prawnych - w dużej mierze decydują o lokalizacji 
obiektów hotelowych. Hotelarstwo z jednej strony cechuje silna unifikacja poprzez kategoryzację, turysta, korzystając z tej samej sieci hotelowej, może liczyć na podobny standard usług, obojętnie w której części świata się znajduje. To wymusza na sieciach lokalizowanie swoich obiektów w możliwie dużej liczbie regionów turystycznych, dzięki temu zyskuje się lojalność klientów. Z drugiej strony pojawiają się nowi turyści, którzy są „zmęczeni” wystandaryzowaną przestrzenią i szukają autentyczności i oryginalności (Durydiwka, Duda-Gromada, 2011), którą mogą znaleźć w tanich lokalnych hotelach lub też w drogich ekskluzywnych hotelach butikowych.

Przez ,politykę lokalizacyjną” realizowaną przez sieci hotelowe można rozumieć, zarówno całokształt decyzji i działań podejmowanych w celu wejścia na dany rynek, jak i poczynania mające na celu uruchomienie w konkretnym miejscu nowego obiektu (Kowalczyk, 1999). Konsekwencją polityki lokalizacyjnej jest usytuowanie obiektu noclegowego w regionie. Inwestorzy kierują się wieloma względami, ale celem nadrzędnym jest osiągnięcie zysku, a to jest możliwe pod warunkiem wysokiego wykorzystania bazy noclegowej. W polityce lokalizacyjnej systemy hotelowe muszą uwzględniać przede wszystkim potrzeby turystów i motywy ich podróżowania, dlatego szczególnego znaczenia nabierają badania rynku mające na celu określenie profilu turysty odpoczywającego w danym kraju.

W regionie Karaibów rozwija się przede wszystkim turystyka wypoczynkowa. Uprzywilejowane warunki klimatyczne, ciepłe morze, możliwości całorocznego odpoczynku decydują o atrakcyjności turystycznej regionu. Dodatkowym argumentem jest ciekawa kultura tych regionów, a w przypadku Kuby - dziedzictwo kultury materialnej (dziewięć obiektów wpisanych na listę UNESCO). Tego typu uwarunkowania (przyrodnicze i pozaprzyrodnicze) oraz model rozwoju turystyki w regionie karaibskim decydują, że do najatrakcyjniejszych inwestycyjnie należą obszary nadmorskie oraz historyczne miasta.

Kraje regionu karaibskiego charakteryzują się bardzo wysokim stopniem bezpieczeństwa turystów. Jest to jeden z ważniejszych czynników podkreślanych zarówno przez osoby odpoczywające, jak i zagranicznych inwestorów. Siła argumentu bezpieczeństwa turystów jest olbrzymia, a jej brak może nawet doprowadzić do upadku funkcji turystycznej regionu. Od wielu lat obserwuje się na rynku turystycznym zjawisko „,sterylizacji wysp”, polegające na usuwaniu z wyspiarskiej rzeczywistości „elementów niebezpiecznych”. Wyspy turystyczne przedstawiane są jako obszary powszechnej szczęśliwości i tropikalnego raju (Jędrusik, 2005; Sheller, 2004).

Z ekonomicznego punktu widzenia niezmiernie ważnym zagadnieniem jest stabilność polityczna władz kraju, które mają bezpośredni wpływ na politykę rozwoju regionalnego oraz uwarunkowania własnościowe, podatkowe, koncesyjne. Powyższe czynniki decydują, czy dany kraj jest postrzegany przez inwestorów jako sprzyjający nowym inwestycjom, czy też jako mało bezpieczny inwestycyjnie. Kuba należy do krajów o bardzo dużej stabilności w zakresie otoczenia inwestycyjnego. Zdecydowane stanowisko władz kraju, mówiące o konieczności rozwijania turystyki, a w szczególności zagospodarowania turystycznego, powoduje, że zagraniczni inwestorzy (kanadyjscy, hiszpańscy, niemieccy) podejmują ryzyko inwestycyjne i otwierają nowe hotele w różnych częściach wyspy. Dodatkowym argumentem jest fakt, że państwo kubańskie jest większościowym udziałowcem przeważającej liczby 
obiektów hotelarskich, w związku z tym władze są bezpośrednio zainteresowane nie tylko określaniem ram polityki regionalnej dotyczącej turystyki, ale także uczestniczą w realizacji własnych i międzynarodowych projektów turystycznych.

Ważnym elementem strategii rozwojowej wielu sieci hotelowych jest szczegółowa analiza czynników warunkujących i elementów różnicujących poszczególne regiony turystyczne, które dążą do osiągnięcia przewagi konkurencyjnej w stosunku do pozostałych. W przypadku całego obszaru karaibskiego czynniki warunkujące są podobne do siebie i należą do nich:

- przeważający typ turystyki - wypoczynkowa (3S),

- silny stopień koncentracji przestrzennej zagospodarowania turystycznego,

- sezonowość ruchu turystycznego,

- przewaga odpoczynku typu all inclusive,

- bardzo dobra zewnętrzna dostępność komunikacyjna obszarów generujących ruch turystyczny.

Natomiast elementy różnicujące Kubę od pozostałej części Karaibów to bogate dziedzictwo kulturowe (Hawana, Trynidad, Cienfuegos, Santiago de Cuba), unikatowe obszary przyrody chronionej (dolina Vinales, Półwysep Zapata, Jardin del Rey), kultura niematerialna (salsa, cabaneros, cygara, rum, santeria) oraz współczesna historia Kuby jako skansenu komunizmu. Ten ostatni element w przypadku wielu biur podróży jest jednym z ważniejszych haseł reklamowych.

\section{PolityKa PRZESTRZENNA włAdZ Kuby w ZAKRESIE ROZWOJU HOTELARSTWA}

Turystyka na Kubie posiada bardzo długie tradycje. Jednym z pierwszych ośrodków turystycznych wyspy była jej stolica Hawana, a następnie Varadero. W latach 50. XX wieku Hawana była głównym ośrodkiem turystycznym dla bogatych Amerykanów, już wtedy określano ją jako „Riviera of the Caribbean”, „Monte Carlo of Latin America” oraz „Paris of the West Indies” (Whittle, Lindeman, Tripp, 2003). Niestety, okres ten obfitował w szereg dysfunkcji związanych z turystyką, takich jak: prostytucja, przestępczość zorganizowana, handel narkotykami, hazard oraz olbrzymie rozwarstwienie społeczeństwa kubańskiego. Te przykre doświadczenia spowodowały, że po zwycięstwie rewolucji i wprowadzeniu nowego systemu społeczno-gospodarczego wyeliminowano turystykę jako rodzaj działalności gospodarczej.

Dopiero lata 80. przyniosły znaczące zmiany w prawodawstwie, które otworzyły kraj dla inwestycji zagranicznych w branży turystycznej. W 1982 roku na mocy ustawy nr 50 zezwolono na współpracę z firmami czy też kapitałem zagranicznym, w związku z tym zaczęły powstawać spółki kapitału mieszanego typu joint venture. W 1987 roku rozpoczęła działalność jedna z największych i do dzisiaj funkcjonujących spółek Cubanacan (Korporacja Handlu Zagranicznego i Turystyki), która w maju 1990 roku otworzyła pierwszy hotel w Varadero, w kooperacji z hiszpańskim inwestorem Melia, a w kolejnych latach oddała do użytku dwa następne hotele o łącznej pojemności 1400 miejsc noclegowych (Cervino, Cubillo, 2005). W 1988 roku do życia została powołana Gaviota, spółka z udziałem kapitału zagranicznego. 
Równocześnie podpisywano liczne kontrakty menedżerskie, m.in. z partnerami niemieckimi (LTI) oraz jamajskimi (Superclubs). Początek lat 90. przyniósł kolejne regulacje w zakresie nowych form działalności gospodarczej na Kubie. Do najważniejszych należały zmiany w przepisach określających funkcjonowanie przedsiębiorstw z kapitałem mieszanym (joint ventures), działających przede wszystkim w branży turystycznej lub w szeroko rozumianym otoczeniu (Perez-Lopez, 1995; Perez-Lopez, 2001).

Turystyka jest zjawiskiem gospodarczym wykazującym się silnym stopniem koncentracji przestrzennej, wynikającym z atrakcyjności turystycznej obszarów. Dla potrzeb dalszego planowania rozwoju turystyki na Kubie, przede wszystkim w jej aspekcie przestrzennym, wydzielono sześć podstawowych regionów turystycznych. Są to: Hawana, Varadero, Ciego de Avilla, Holugin, Santiago de Cuba oraz Cayo Largo Sur, które bardzo często określane są jako bieguny wzrostu (Núñez, Fernández, 2011). Wydzielone jednostki przestrzenne charakteryzują się bardzo dobrym zagospodarowaniem turystycznym, tu znajduje się około 70\% miejsc noclegowych, oraz dużym natężeniem ruchu turystycznego ( $88 \%$ zagranicznego ruchu turystycznego). Ministerstwo Turystyki (MINTUR) nie tylko określa regiony, w których powstają inwestycje turystyczne, ale także ma ściśle sprecyzowane stanowisko w zakresie charakteru urbanistycznego ośrodków turystycznych. MINTUR dokonał szczegółowej delimitacji 85 obszarów (polo turistico), w których mogą powstawać nowe inwestycje i jasno określił warunki zabudowy:

- jedynie 40 pokoi może przypadać na 1 ha użytkowanego terenu,

- 75\% obszaru ośrodka musi pozostać wolne od zabudowy,

- dopuszczalna jest jedynie niska zabudowa, do 4 kondygnacji.

Powyższe przepisy nie dotyczą inwestycji powstających w miastach.

Specyfika systemu gospodarczego Kuby wpływa bezpośrednio na charakter i zakres zmian w układach przestrzennych wszystkich rodzajów działalności gospodarczej. Przyzwolenie polityczne władz jest najważniejszym czynnikiem determinującym rozwój branży turystycznej, zarówno w zakresie ilościowym, jakościowym, jak i przestrzennym. Dlatego też z dwóch powodów systemy hotelowe mają ograniczone możliwości decyzyjne dotyczące nowych inwestycji. Pierwszym z nich jest odgórne wyznaczenie obszarów przeznaczonych pod tego typu działalność, a drugim - obecność współudziałowców w postaci państwa kubańskiego.

\section{KUBAŃSKIE ENKLAWY TURYSTYCZNE}

Kuba ze względu na swoją sytuację społeczno-gospodarczą jest zaliczana do grupy krajów rozwijających się, dla których cechą charakterystyczną układów przestrzennych obszarów turystycznych jest tworzenie się enklaw turystycznych. Enklawy turystyczne z reguły powstają w krajach o pewnym stopniu niestabilności politycznej, społecznej i ekonomicznej, a głównymi przyczynami ich funkcjonowania są: bezpieczeństwo, ograniczone zasoby finansowe społeczności lokalnych, ograniczona liczba przedsiębiorców lokalnych, którzy mogą 
zainwestować w branżę turystyczną. Wydzielanie i działanie enklaw turystycznych przynosi szereg skutków dla rozwoju społeczno-gospodarczego regionów. Są to elementy pozytywne, takie jak tworzenie miejsc pracy dla miejscowej ludności, poprawa infrastruktury technicznej bezpośredniego otoczenia poprzez jej rozbudowę i polepszenie dostępności komunikacyjnej. Ale niestety coraz częściej podkreśla się ich negatywne aspekty: zmniejszenie dochodów firm lokalnych w wyniku oferowania pakietów turystycznych typu all inclusive, zależność od zagranicznych inwestycji oraz firm, bardzo wysoki poziom wycieków dewizowych, niskie powiązanie enklaw turystycznych z lokalnym rynkiem (lokalnych towarów i usługi), co wynika przede wszystkim z niskiej jakości produktów miejscowych i sezonowości zatrudnienia. Nieprawidłowe postrzeganie destynacji turystycznej poprzez pryzmat warunków w enklawach turystycznych, koncentracja przestrzenna i czasowa powodują bardzo duże obciążenie dla środowiska przyrodniczego, ograniczają korzyści ekonomiczne wynikające z rozwoju turystyki dla ludności miejscowej, dają niewielkie możliwości poznania miejscowej tradycji i kultury.

Bardzo często enklawy turystyczne na Karaibach są porównywane do statków wycieczkowych unoszących się na wodach Morza Karaibskiego, niemających umocowania (integracji) w gospodarce tych krajów. Enklawy turystyczne należą do wielkich korporacji ponadnarodowych, a ich powstanie ma na celu ściągnięcie bogatego turysty, co decyduje o jego elitarnym charakterze. To przynosi znacznie większe dochody dewizowe niż inne formy ruchu turystycznego.

Do głównych cech charakterystycznych enklaw turystycznych należą:

- bardzo wysoki stopień koncentracji przestrzennej,

- są to jednostki przestrzenno-funkcjonalne o charakterze zamkniętym (fizycznie, społecznie i ekonomicznie) i bardzo często samowystarczalnym,

- w większości przypadków wielkość ruchu turystycznego w enklawach turystycznych jest zależna od turystów zagranicznych (orientacja na zewnątrz),

- styl życia w sposób zasadniczy różni się od otoczenia,

- finansowanie zewnętrzne,

- koncentrowanie się na określonym segmencie rynku (turystyka wypoczynkowa all inclusive),

- w wielu krajach enklawy turystyczne powstają na pionierskim etapie rozwoju turystyki, jako pierwsze i bardzo często jedyne formy zagospodarowania turystycznego.

Kuba jest idealnym przykładem mechanizmu powstawania enklaw turystycznych, które charakteryzują się wręcz maksymalną izolacją turystów od środowiska lokalnego. Wynika to z kilku faktów, m.in. z tego, że powstają one na przyrodniczo izolowanych obszarach, jakimi są wyspy, połączone z otoczeniem groblami i lotniskami. Do najbardziej charakterystycznych enklaw należą: Cayo Coco, Cayo Santa Maria i Cayo Largo (ryc. 1). 


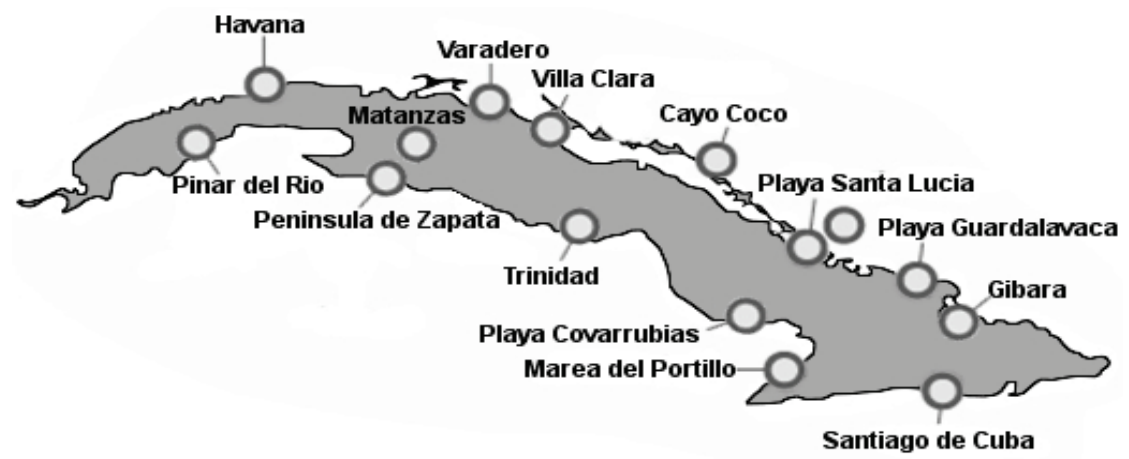

Ryc. 1. Regiony turystyczne (polo turistico) Kuby

Źródło: opracowanie własne

Jednym z ważniejszych regionów recepcji turystycznej na Kubie są wyspy należące do archipelagu Sabana-Camaguey, na który składa się 2,5 tys. wysp położonych na przestrzeni 450 km. Rozciągają się one od Punta Maternillos na wyspie Cayo Sabinal w prowincji Camaguey aż do Punta Hicacos na półwyspie Varadero w prowincji Matanzas. Częścią tego archipelagu jest Jardines del Rey, grupa wysp o długości $200 \mathrm{~km}$. Do najlepiej zagospodarowanych wysp Jardines del Rey należą: Cayo Coco, Cayo Guillermo oraz Cayo Santa Maria. Wyspy te leżą na terenie prowincji Ciego de Avila i Villa Clara.

Cayo Coco jest połączone z główną wyspą 27-kilometrową groblą, która została oddana do użytku w 1988 roku, natomiast lotnisko na wyspie rozpoczęło działalność w 2002 roku. Wcześniej turyści korzystali z międzynarodowego lotniska w Ciego de Avila. Prace budowlane przy hotelach zostały rozpoczęte w 1988 roku, natomiast pierwszy hotel został oddany do użytku w 1993 roku. Na terenie wyspy funkcjonuje 10 obiektów hotelarskich o łącznej pojemności 3483 pokoi. Trzy hotele należą do grupy Melia, dwa do Iberostar, dwa do Blue Diamond, natomiast trzy są administrowane przez przedsiębiorstwa kubańskie. Najnowszą inwestycją (2012 rok) jest pięciogwiazdkowy hotel Memories Flamenco Beach Resort (Cuban Group Gaviota) o pojemności 624 pokoi. Docelowo planuje się powstanie 50 hoteli o łącznej pojemności 20 tys. pokoi. Na wyspie znajduje się marina oraz pole golfowe (dwa dalsze są w budowie). Cayo Coco stanowi także miejsce szkoleniowe dla pracowników branży turystycznej. W ostatnim rankingu Traveler's Choice Edition 2012 plaże Cayo Coco zajęły 20 miejsce wśród najpiękniejszych plaż na świecie.

Bezpośrednio z wyspą Cayo Coco połączona jest Cayo Guillermo - wyspa o powierzchni $13 \mathrm{~km}^{2}$. Tu znajduje się jedna z najpiękniejszych plaż - Pilar, w okolicy można podziwiać najwyższe na Karaibach wydmy o wysokości $16 \mathrm{~m}$. Na wyspie funkcjonują cztery hotele o łącznej pojemności 1093 pokoi, trzy z nich należą do hiszpańskich sieci Sol Melia i Iberostar, natomiast jeden do kubańskiej.

Kolejną enklawą turystyczną jest Cayo Santa Maria leżące na terenie prowincji Villa Clara, która należy do lepiej zagospodarowanych turystycznie obszarów - rocznie udziela się tam 1,18 mln noclegów. Turyści najczęściej odwiedzają Cayo Santa Maria, wyspę połączoną 
groblą (48 km długości) z miastem Caibarien. Jest to jeden z najmłodszych regionów turystycznych Kuby - pierwszy hotel Sol Cayo Santa Maria został otwarty w 2001 roku. Obecnie na wyspie funkcjonuje dziewięć hoteli typu all inclusive o łącznej pojemności 5000 pokoi (2011 rok) oraz międzynarodowy port lotniczy Las Brujas Airport, obsługujący w większości loty czarterowe. Poza hotelami położonymi na plażach i infrastrukturą komunikacyjną wyspy nie posiadały nic więcej, były pozbawione jakichkolwiek punktów osadniczych. W związku z tym zaplanowano i zbudowano centra usługowo-handlowe, które miały na celu połączenie kompleksów hotelowych w zurbanizowane strefy oraz uzupełnienie oferty usługowej hoteli. Przykładem tego typu inwestycji jest Pueblo la Estrella, obszar o powierzchni 65 tys. $\mathrm{m}^{2}$, zarządzany przez kubańską spółkę Gaviota, na którym znajdują się liczne punkty usługowe, sklepy (rzemiosło artystyczne), restauracje, obiekty rozrywkowe, sportowe i rekreacyjne. Drugim tego typu obiektem jest Pueblo Las Dunas, ale o znacznie mniejszych rozmiarach. Wyspa jest połączona groblą z Cayo Ensenachos oraz Cayo Las Brujas.

Teoretycznie enklawa turystyczna jako forma zagospodarowania turystycznego mogłaby spełniać szereg funkcji w otaczającej ją przestrzeni. Według Brenner (Brenner, 2005) może być początkiem do zwiedzania szeroko rozumianego regionu (punktem wyjścia), w tym przypadku jest base camp (Oppermann 1995; Stewart, Vogt, 1997), hub-and-spoke (McKercher, Lew, 2004), base site (Lau, McKercher, 2007), single point-to-point (Lew, McKercher, 2006) or radiating hub (Lew, McKercher, 2006). Lecz niestety w praktyce nie zawsze rozwój enklaw turystycznych przynosi wymierne korzyści ekonomiczne (Derek, 2007; Kauppila, 2010).

Ważnym pytaniem jest, czy tylko czynnik polityczny decyduje o lokalizacji hoteli w enklawach turystycznych, czy też turyści jako klienci hoteli są zadowoleni z odpoczynku w izolowanych, bezpiecznych, ekskluzywnych ośrodkach wypoczynkowych. Odpowiedź nie jest prosta i jednoznaczna, ponieważ czynnik polityczny jest podstawowy - władze kraju zadecydowały o izolacji Kubańczyków od turystów i odwrotnie. Równocześnie badania potwierdzają, że ze strony turystów jest bardzo duże zapotrzebowanie na typ odpoczynku, gdzie bezpieczeństwo jest priorytetem.

\section{DOSTĘPNOŚĆ KOMUNIKACYJNA JAKO ELEMENT POLITYKI LOKALIZACYJNEJ SIECI HOTELOWYCH}

Jednym z ważniejszych czynników lokalizacji infrastruktury turystycznej jest zewnętrzna dostępność komunikacyjna, szczególnie w regionach turystycznych nastawionych na obsługę zagranicznej turystyki przyjazdowej. Wynika to przede wszystkim ze zmiany modelu odpoczynku. Współcześnie przeciętny turysta w ciągu roku wyjeżdża kilka razy, ale na krótszy odpoczynek, w związku z tym skraca się też przeciętna długość pobytu. Turyści są zainteresowani bardzo krótkim czasem podróży, dlatego tak dużego znaczenia nabrał transport lotniczy. Koniecznością stało się budowanie lotnisk w bezpośrednim sąsiedztwie regionów recepcji turystycznej i jest to związane z ograniczaniem czasu dojazdu z lotniska do hotelu. 
Kuba jest krajem posiadającym bardzo dobrą infrastrukturę naziemną lotnictwa. Na jej obszarze funkcjonuje sześć cywilnych lotnisk międzynarodowych, cztery lotniska wojskowe udostępnione dla pasażerskiego ruchu międzynarodowego oraz 15 lotnisk krajowych (ryc. 2).

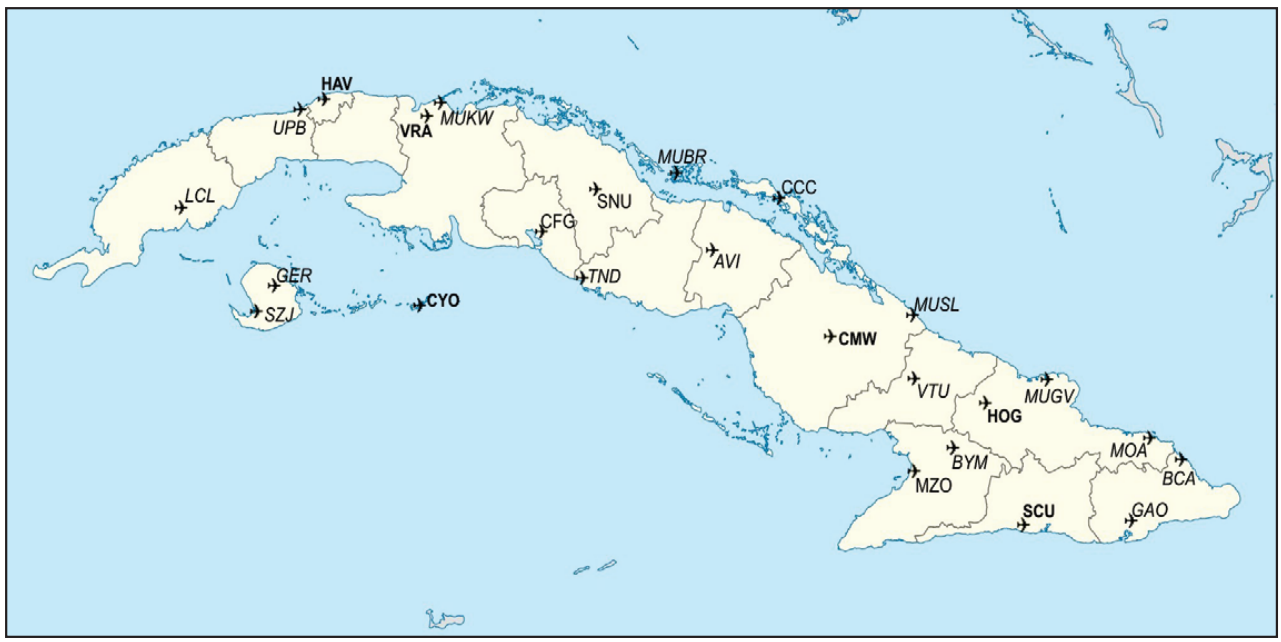

Ryc. 2. Położenie portów lotniczych na Kubie

Objaśnienia skrótów do ryc. 2

\begin{tabular}{|c|c|c|c|c|}
\hline \multirow{2}{*}{ Lp. } & \multicolumn{2}{|c|}{ Kod lotniska } & \multirow{2}{*}{ Pełna nazwa portu lotniczego } & \multirow{2}{*}{ Położenie (prowincja) } \\
\hline & IATA & $\mathrm{ICAO}$ & & \\
\hline \multicolumn{5}{|c|}{ cywilne lotniska międzynarodowe } \\
\hline 1 & HAV & MUHA & Aeropuerto Jose Marti & Habana (Ciduad de la Habana) \\
\hline 2 & VRA & MUVR & Aeropuerto J. G. Gómez & Varadero (Matanzas) \\
\hline 3 & $\mathrm{CYO}$ & MUCL & Aeropuerto Vitalio Acuña & Cayo Largo (Isla de la Juventud) \\
\hline 4 & CMW & MUCM & Aeropuerto Ignacio Agramonte & Camagűey (Camagüey) \\
\hline 5 & HOG & MUHG & Aeropuerto Frank Pais & Holguín (Holguín) \\
\hline 6 & SCU & MUCU & Aeropuerto Antonio Maceo & Santiago de Cuba (Santiago de Cuba) \\
\hline \multicolumn{5}{|c|}{ lotniska wojskowe udostępnione dla pasażerskiego ruchu międzynarodowego } \\
\hline 7 & CFG & MUCF & Aeropuerto Jaime González & Cienfuegos (Cienfuegos) \\
\hline 8 & SNU & MUSC & Aeropuerto Abel Santamaría & Santa Clara (Villa Clara) \\
\hline 9 & $\mathrm{CCC}$ & MUCC & Aeropuerto Jardines del Rey & Cayo Coco (Ciego de Ávila) \\
\hline 10 & $\mathrm{MZO}$ & MUMZ & Aeropuerto Sierra Maestra & Manzanillo (Granma) \\
\hline
\end{tabular}

Źródło: opracowanie własne na podstawie danych IACC (Instituto de Aeronáutica Civil de Cuba)

Spośród wszystkich portów lotniczych Kuby największe znaczenie ma lotnisko w Hawanie, obsługujące przede wszystkim loty rejsowe. Typowym lotniskiem turystycznym jest Varadero, położone na terenie prowincji Matanzas i ono zajmuje pierwsze miejsce pod względem odprawionych pasażerów - są to przede wszystkim loty czarterowe. Jest położone w odległości $25 \mathrm{~km}$ od obszaru wypoczynkowego na półwyspie Hicacos oraz $100 \mathrm{~km}$ od Hawany. Niestety, nie są publikowane oficjalne statystyki dotyczące liczby odprawianych pasażerów i jedynie sugerując się wielkością ruchu turystycznego w poszczególnych ośrodkach, można wnioskować o randze lotniska. Lotnisko w Holguin obsługuje turystów 
odpoczywających w Guardalavaca. Lotnisko Jardines del Rey na Cayo Coco powstało na potrzeby obsługi ruchu turystycznego w obrębie dwóch enklaw: Cayo Coco i Cayo Guillermo. Odległość lotniska od hoteli waha się od 10 do $40 \mathrm{~km}$. Podobna sytuacja ma miejsce w przypadku lotniska Vitalio Acuña na wyspie Cayo Largo, obsługującego enklawę turystyczną, w tym przypadku odległość od hoteli waha się od 5 do $7 \mathrm{~km}$. Wszystkie wyżej wymienione lotniska, poza Hawaną, posiadają przede wszystkim połączenia z miastami w Kanadzie (Montreal, Toronto, Calgary, Ottawa, Quebec) oraz w Europie Zachodniej.

Sieć lotnisk i ich połączenie z głównymi obszarami recepcji turystycznej na Kubie decyduje o jej bardzo dobrej dostępności komunikacyjnej, co w sposób bezpośredni wpływa na podejmowanie decyzji o lokalizacji hoteli w konkretnych miejscach.

\section{ChARAKTERYSTYKA WYBRANYCH SYSTEMÓW HOTELOWYCH DZIAŁAJĄCYCH NA KUBIE}

W przypadku Kuby trudno jest mówić o konkurencyjności podmiotów gospodarczych działających w branży turystycznej, gdyż wiadomym jest, że instytucje lub przedsiębiorstwa turystyczne mogły powstawać jedynie z przyzwolenia politycznego. Początek lat 80. oznaczał dla Karaibów okres intensywnego wznoszenia hoteli nadmorskich typu all inclusive. Na rynku kubańskim obserwuje się silny stopień specjalizacji sieci hotelowych w zakresie typów i standardów obiektów hotelowych. Aktualnie Kuba dysponuje 270 hotelami o pojemności 48,3 tys. pokoi, które głównie są przeznaczone dla turysty zagranicznego. Są to hotele o bardzo wysokim standardzie, $68 \%$ to obiekty cztero- i pięciogwiazdkowe, w większości położone na plaży $(68 \%)$ oraz w miastach $(25 \%)$. Cechą charakterystyczną zagospodarowania turystycznego jest zjawisko koncentracji przestrzennej - 32\% potencjału przypada na Varadero, a 22\% na Hawanę.

Kuba jest jedynym krajem regionu karaibskiego, w którym udział państwa w branży turystycznej jest dominujący i jedynie spółki z kapitałem mieszanym (hiszpańskim, kanadyjskim, niemieckim) mają polityczne przyzwolenie na działania. W większości krajów, takich jak: Dominikana, Meksyk, Jamajka, obiekty hotelowe należą do zagranicznych inwestorów, co znacznie obniża pozytywne oddziaływanie branży turystycznej na rozwój społeczno-gospodarczy regionu. Jedną z największych sieci hotelowych na Kubie jest Gran Caribe, prowadząca 41 hoteli o łącznym potencjale 10,8 tys. pokoi; są to obiekty cztero- i pięciogwiazdkowe, położone przede wszystkim w Varadero i Hawanie. Flagowymi hotelami tej sieci są: Hotel Nacional de Cuba, Hotel Plaza, Hotel Inglaterra i Hotel Casa Granda. Najstarszą siecią jest Cubanacan S.A., która administruje 60 obiektami o potencjale 13 tys. pokoi, a do bardziej znanych należą: Hotel Versalles w Santiago de Cuba i Hotel Faro Luna w Cienfuegos. Sieć Hotelera Horizontes posiada obiekty o niższym standardzie (dwu-, trzy-, czterogwiazdkowe), jest ich 44 o łącznej pojemności 7 tys. pokoi. Grupo Gaviota administruje hotele cztero- i pięciogwiazdkowe o łącznej pojemności 8,6 tys. pokoi. Sieć Habaguanex S.A. zarządza hotelami miejskimi, jest ich 16 (400 pokoi) - są to małe obiekty położone w historycznych 
częściach miast, a do najbardziej znanych należą: Hotel Raquel, Hotel Florida, Hotel Santa Isabel i Hotel Ambos Mundos. Sektor turystyki krajowej obsługuje grupa Islazul.

Jedną z najmocniejszych pozycji na rynku kubańskim zajmuje hiszpańska sieć hotelowa, która powstała w 1956 roku pod nazwą Sol Melia. W 2011 roku nazwa uległa zmianie i obecnie jest to Melia Hotels International. W światowych rankingach znajduje się ona w grupie 20 najlepszych sieci hotelowych, posiada 350 hoteli w 35 krajach. Pod jej marką funkcjonują następujące hotele: Meliá Hotels, TRYP Hotels, Sol Hotels, Paradisus Resorts, Hard Rock and Sol Meliá Vacations Club. Firma zatrudnia 35000 pracowników.

Do tej sieci hotelowej należą hotele $\mathrm{z}$ całego świata i działają pod markami: Melia (104 hotele), Tryp (91), Sol Hotels (66), Innside (13), Paradisus Resorts (10), Gran Melia (11 hoteli - 3), Me By Melia (4). Jest to sieć hotelowa posiadająca swoje placówki w prawie wszystkich krajach regionu amerykańskiego. Ale najwięcej hoteli sieci Melia znajduje się na Kubie - 26, w Brazylii - 12, Meksyku - dziewięć oraz na Dominikanie - pięć.

Tab. 1. Hotele sieci Melia Hotels International na Kubie w 2012 roku

\begin{tabular}{|l|c|c|}
\hline \multicolumn{1}{|c|}{ Regiony turystyczne } & Liczba obiektów & Liczba pokoi \\
\hline Cayo Coco & 3 & 1027 \\
\hline Cayo Guillermo & 2 & 569 \\
\hline Cayo Largo & 2 & 603 \\
\hline Cayo Santa Maria & 4 & 1688 \\
\hline Hawana & 3 & 1431 \\
\hline Holguin & 2 & 818 \\
\hline Santiago de Cuba & 1 & 302 \\
\hline Varadero & 9 & 4709 \\
\hline Razem & 26 & 11147 \\
\hline
\end{tabular}

Źródło: solmelia.com

Największa liczba hoteli sieci Sol Melia występuje na terenie najstarszego regionu turystycznego Varadero, jest on obecnie najpopularniejszą destynacją wypoczynkową na Kubie. Na podstawie powyższych danych można wnioskować, że głównym celem strategicznym systemów hotelowych jest obecność we wszystkich regionach turystycznych (polo turistico). Ta polityka lokalizacyjna ma wpływ na kształtowanie się układów przestrzennych związanych z obsługą ruchu turystycznego. Nawet kryzys gospodarczy, który dotknął inwestorów z krajów Europy Zachodniej, nie spowodował zahamowania działań budowlanych, ponieważ w przypadku Kuby występuje niedobór elementów infrastruktury turystycznej. Równocześnie należy pamiętać, że kubańska branża turystyczna „szykuje” się na otwarcie rynku amerykańskiego - zniesienie embarga może gwałtownie zwiększyć wielkość zagranicznego ruchu turystycznego. 
Podsumowanie

Turystyka w przypadku wielu krajów jest jedną z możliwych dróg rozwoju gospodarczego, ale pod warunkiem zminimalizowania kosztów środowiskowych, gospodarczych i społecznych. Wydaje się być zasadnym stwierdzenie, że Kuba jako jeden z nielicznych krajów regionu karaibskiego poradziła sobie bardzo dobrze z problemem inwestycji zagranicznych w sektorze turystycznym i wyciekaniem dewiz poza kubańską gospodarkę. Rozwiązanie polegające na łączeniu kapitału zagranicznego z krajowym (państwowym) poprzez tworzenie spółek joint venture spowodowało większą kontrolę przepływów finansowych. Władze Kuby podjęły trudną decyzję, by turystyka była czynnikiem aktywizującym pozostałe sektory gospodarki kraju, a kapitalistyczne środki finansowe wspomagały rozwój socjalizmu (Matthews, 1977).

W literaturze spotyka się określenie ,agresywnie” rozwijającej się turystyki na Kubie, oznaczające dynamiczny wzrost liczby nowych obiektów noclegowych oraz infrastruktury towarzyszącej. Według planów Ministerstwa Turystyki, rocznie będzie przybywać ok. 3 tys. nowych pokoi hotelowych. Polityka lokalizacyjna systemów hotelowych działająca na wyspie opiera się na zasadzie procesów koncentracji, w związku z tym można wyodrębnić cztery priorytetowe regiony turystyczne: Hawana, Varadero, Sabana-Camaguey i północne Holguin. Perspektywicznie nastąpi uzupełnienie produktu turystycznego o pola golfowe (trzy - cztery), mariny i porty morskie (trzy). Według opinii Ministerstwa Turystyki, na jedno pole golfowe docelowo powinno przypadać ok. 2000 pokoi hotelowych.

Przykładem agresywnego rozwoju turystyki są północne obszary prowincji Ciego de Avilla, a w szczególności wyspy Cayo Coco i Cayo Guillermo, gdzie w krótkim czasie powstało kilkanaście tysięcy miejsc noclegowych, port lotniczy, 200 km nowych dróg, $100 \mathrm{~km}$ wodociągu prowadzącego wodę na wyspy oraz dwie groble łączące te obszary z główną wyspą. W dalszym ciągu szereg nowych inwestycji hotelarskich jest prowadzonych w Varadero - najstarszym i największym obszarze recepcji turystycznej. Zainwestowanie infrastrukturalne na półwyspie Hicacos jest tak wielkie, że powoli turystyka uruchamia proces samozniszczenia poprzez intensywność ruchu turystycznego. W dalszym ciągu powstają nowe hotele w Varadero, co jest spowodowane faktem, że w ogólnej świadomości turystów jest to główny i bardzo często jedyny ośrodek turystyki wypoczynkowej na wyspie. Marka tego obszaru jest magnesem przyciągającym podróżnych z wielu regionów świata, drugim atutem tego miejsca jest bliskie sąsiedztwo Hawany jako największej atrakcji turystycznej Kuby.

Sieci hotelowe nie inwestują na obszarach, na których dominującą formą ruchu turystycznego będzie ekoturystyka, takich jak: półwysep Zapata, rejon górski Sierra del Rosario, okolice Vinales czy też archipelag wysp na południu Jardines de la Reina. Tereny te są przeznaczone dla małych hoteli obsługiwanych przez ludność miejscową (Moka Ecolodge w prowincji Pinar del Rio).

Jeszcze przez kilkanaście najbliższych lat największym zainteresowaniem inwestorów będą się cieszyły enklawy turystyczne i pomimo szeregu negatywnych skutków, jakie wywołują, w dalszym ciągu będą się rozwijały. W wielu krajach karaibskich podjęto 
kroki zmierzające do eliminacji szkodliwego oddziaływania enklaw turystycznych poprzez propagowanie alternatywnych form turystyki. Zostało to sformalizowane w ramach rządowych programów takich krajów, jak: Saint Vincent i Grenadyny, Jamajka, Dominika oraz Portoryko i Gwadelupa. Na Kubie również zainicjowano działania instytucjonalne zmierzające do promowania Kuby na międzynarodowym rynku usług turystycznych nie tylko jako regionu turystyki wypoczynkowej all inclusive. Jednym z przykładów jest udział kraju w Międzynarodowych Targach Turystycznych FITUR 2012 w Madrycie z akcją promocyjną „Autentyczna Kuba”, której podstawą jest rozszerzenie produktu turystycznego o elementy turystyki przyrodniczej, kulturowej oraz konferencyjnej. Szanse rozwojowe turystyki kubańskiej będą zależały od dalszej dywersyfikacji produktu turystycznego, a więc uwzględnienia w planach długoterminowy także odpoczynku określanego mianem snowbird. Jest on charakterystyczny dla mieszkańców strefy umiarkowanej Ameryki Północnej i Europy Zachodniej, którzy w okresach zimowych wyjeżdżają do krajów znacznie cieplejszych (pod względem klimatu), gdzie mogą, choć nie muszą, mieć swoje mieszkania, domy czy rezydencje.

\section{Literatura \\ References}

Brenner, L. (2005). State-planned tourism destinations: the case of Huatulco, Mexico. Tourism Geographies, vol. 7, 138-164.

Cervino, J., Cubillo, J.M. (2005). Hotel and tourism development in Cuba. Opportunities, management, challenges, and future trends. Cornell Hotel and Restaurant Administration Quarterly, 46(2), 223-246.

Derek, M. (2007). Od wioski rybackiej do turystycznej enklawy? Turystyka a rozwój lokalny na przykładzie Mikołajek. Studia Regionalne i Lokalne, 2(28), 112-127.

Durydiwka, M., Duda-Gromada, K. (2011). Między autentycznością a kreacją - tendencje i przyczyny zmian w przestrzeni turystycznej. Przestrzeń turystyczna. Czynniki, różnorodność, zmiany. Warszawa: Uniwersytet Warszawski, Wydział Geografii i Studiów Regionalnych, 53-63.

Jędrusik, M. (2005). Wyspy tropikalne. W poszukiwaniu dobrobytu. Warszawa: Wydawnictwa Uniwersytetu Warszawskiego.

Kauppila, P. (2010). Resorts and regional development at the local level: a framework for analysing internal and external factors. Nordia Geographical Publications, 39(1), 39-48.

Kowalczyk, A. (1999). Polityka lokalizacyjna wybranych systemów hotelowych. Turyzm, 9(1), Łódź: Uniwersytet Łódzki, 137-159.

Kowalczyk, A. (2001). Geografia hotelarstwa. Łódź: Wydawnictwo Uniwersytetu Łódzkiego.

Lau, G., McKercher, B.(2007). Understanding the Movement Patterns of Tourists in a Destination: A GIS Approach. Tourism and Hospitality Research, 7(1), 39-49.

Lew, A., Mc Kercher, B. (2006). Modeling tourist movement: a local destination analysis. Annals of Tourism Research, 33(2), 403-423.

Matthews, H.G. (1977). Radicals and third world tourism: A caribbean focus. Annals of Tourism Research, 5(1), 20-29.

McKercher, B., Lew A.A. (2004). Tourist flows and the spatial distribution of tourists. W: A.A. Lew, C.M. Hall, A.M. Williams (red.): A companion to tourism. Blackwell, Malden, Oxford and Carlton, 36-48. 
Núñez, G.G., Fernández, R.O. (2011). Cuba y el turismo norteamericano. Analisis de potencialidades y de impactos en la región caribeña. Cuba Futures Series, 141-199.

Oppermann, M. (1995). A model for travel itineraries. Journal of Travel Research, 33, 57-61.

Pérez-López, J.F. (1995). Cuba's Second Economy: From Behind the Scenes to Center Stage. New Brunswick, NJ: Transaction Books.

Pérez-López, J.F.(2001). Cuba's SocialistEconomy: the Mid-1990s. W:I.L. Horowitz, J. Suchlicki,(red.). Cuban Communism. 10. wyd. New Brunswick: Transaction Publishers, 205-236.

Sheller, M. (2004). Natural Hedonism: The Invention of Caribbean Islands as Tropical Playgrounds. W: S. Courtman (red.) Beyond the Blood, the Beach and the Banana: New Perspectives in Caribbean Studies. Kingston: Ian Randle.

Stewart, S.I., Vogt, C.A. (1997). Multi-destination trip patterns. Annals of Tourism Research, 24, 458-461. Whittle D.J., Lindeman K.C., Tripp J.T.B. (2003). International Tourism and Protection of Cuba's Coastal and Marine Environments. Tulane Environmental Law Journal, 16, 1-57.

Renata Rettinger, doktor, adiunkt, Uniwersytet Pedagogiczny w Krakowie, Instytut Geografii, Zakład Turystyki i Badań Regionalnych.

Autorka koncentruje się w badaniach na problematyce rozwoju turystyki w regionie karaibskim. W problematyce badawczej przeważają tematy dotyczące wielkości i przestrzennego zróżnicowania zagospodarowania oraz ruchu turystycznego, a w szczególności kierunki rozwoju turystyki. W opracowaniach przewija się także tematyka enklaw turystycznych jako dominującej formy zagospodarowania turystycznego na Karaibach w kontekście rozwoju zrównoważonego i turystyki pro-poor.

Renata Rettinger, Ph.D. In her research, the author concentrates on the problems of tourism development in the Caribbean region. The dominating research topics are the size and spatial differentiation of tourist infrastructure and tourism volume itself together with the directions of the tourism development. The research topics also include the issue of tourist enclaves as a dominating form of tourist infrastructure in the Caribbean region in light of sustainable development and pro-poor tourism.

\section{Adres/address:}

Uniwersytet Pedagogiczny w Krakowie

Instytut Geografii

Zakład Turystyki i Badań Regionalnych

ul. Podchorążych 2, 30-084 Kraków, Polska

e-mail: rettinger@onet.eu 